\title{
The Effects of E-commerce on Franchising: Practical Implications and Models
}

\begin{abstract}
This study investigates the current state of e-commerce in franchising and how this area is affecting franchisee-franchisor relationships. Its main purpose is to investigate and identify viable e-commerce strategies that franchise networks can successfully implement and maintain. The data were gathered through a two-stage process that involved (1) semistructured interviews with franchisors and (2) a moderated industry forum, where franchisors and industry experts openly discussed their strategies and concerns with respect to ecommerce. This was implemented through three-level coding using NVivo software. The first theme identified was the participation of franchisees in developing and executing the ecommerce strategy, the second was a broad theme around franchisee opinions and fears, and the third involved introducing and implementing an e-commerce strategy within an existing franchising model. Finally, an overarching model was created where all key concepts are interrelated and avenues for further research are explored.
\end{abstract}

Keywords: e-commerce, franchising relationships, franchisee engagement, encroachment, franchisee acceptance.

Article Classification: Practitioner Paper 


\section{Overview}

The focus of this research lies within the intersection of two dynamic business strategies: franchising and electronic commerce (e-commerce). Both strategies have received considerable attention from academic researchers across different disciplines, including marketing, IT, consumer behaviour, and organisational theory (Dennis et al., 2009; Weaven et al., 2018; Wright \& McAuley, 2012; Frazer et al., 2014; Weaven et al., 2018). However, some have suggested that the crossover between these two fields has not been sufficiently researched (Cedrola \& Memmo, 2009; Dixon \& Quinn, 2004; Wright \& McAuley, 2012).

Understanding the e-commerce strategy in franchising is vital for a number of reasons. Firstly, any modern business requires a thorough e-commerce strategy if they want to improve their service standard and meet customer needs (Herjanto \& Franklin, 2019; Kaushik et al., 2018; Nisar \& Prabhakar, 2017), and franchised businesses are no exception to this rule (Cliquet \& Voropanova, 2016; Nathan \& Kremez, 2012; Perrigot, Basset, \& Cliquet, 2017). Secondly, from a marketing perspective, franchising can draw multiple potential benefits from effective e-commerce use, such as greater brand recognition and awareness, lead generation, global reach, customisation and personalisation, and greater supply chain efficiencies (Perrigot \& Pénard, 2013; Tagashira \& Minami, 2016; Trinh, Anesbury \& Driesener, 2017). Furthermore, franchising warrants particular attention due to its continuous growth in developed economies such as Australia (1,160 franchise networks), Canada $(1,200$ networks), the United Kingdom (842 networks), and the United States (2,200 networks), as well as in emerging economies such as Brazil (1,643 networks), China (4,000), and India $(1,800)$ (Frazer et al., 2014). 
Also, it is important to study this area due to the inherent contradictions that arise when franchising and e-commerce are combined (Cliquet \& Voropanova, 2016; Perrigot, Basset, \& Cliquet, 2017). On one hand, franchising has traditionally relied on granting exclusivity within protected territories to system members (franchisees) (Frazer, 2000; Wright \& Frazer, 2007). On the other hand, e-commerce is a business strategy that allows for a wider geographical reach of consumers in different markets and does not respect any territorial boundaries (Di Fatta, Patton, \& Viglia, 2018; Chumnumpan \& Shi, 2019; Tagashira \& Minami, 2016; Trinh, Anesbury, \& Driesener, 2017). Thus, when e-commerce was introduced, franchising organisations were faced with challenges that their non-franchised counterparts did not encounter (Emerson, 2010; Perrigot, Basset, \& Cliquet, 2017). A number of franchises adopted ill-considered strategies-often resulting in litigation with their franchisees, as in the case of Dymocks or Drug Emporium (Knack \& Bloodhart, 2001). Similarly, others delayed this decision until recently, such as the retail chain Harvey Norman (Stafford, 2011).

Nevertheless, the global trends of steady growth in e-commerce and the decline in traditional "bricks-and-mortar" retail sales have prompted franchisors to reconsider their reserved approach towards the online offering of products and services (Cliquet \& Voropanova, 2016; Frazer et al., 2014). However, franchisors have continuously struggled to identify the most effective use of e-commerce for their systems - both during the 1990s, when purely online businesses were rapidly emerging, and today, when e-commerce is an established and sustainable strategy (Knack \& Bloodhart, 2001; Perrigot \& Pénard, 2013; Perrigot, Basset, \& Cliquet, 2017). Yet, there is very little empirical research in this field to inform franchisors' decisions to adopt an appropriate e-commerce strategy. The lack of an in-depth understanding 
of e-commerce practices in franchising indicates a need for further research in this area (Cedrola \& Memmo, 2009; Dixon \& Quinn, 2004; Rao \& Frazer, 2010).

By investigating how franchise networks are currently incorporating e-commerce into their operations and marketing, this research aims to assess the development of this strategy in the franchising sector and the approach that such organisations are using to embrace ecommerce. In particular, this research focusses on current e-commerce strategies dealing with encroachment, franchisee relationships, and profit-sharing models, which are the most tenuous areas in the sector (Watson et al., 2002). This goal was addressed using two qualitative research techniques combined: 1) semi-structured interviews; and 2) a moderated industry forum. The findings were interpreted with the help of qualitative data analysis software, NVivo 9, and visually represented using models (Silverman, 2010).

\section{Gaps in the Literature and Proposed Contributions}

E-commerce in franchising has not received a lot of academic attention. Although a few exploratory articles have been published since the early 2000 s, there is still a large gap in the literature on the crossover between franchising and e-commerce (Dixon \& Quinn, 2004). At present, relatively limited literature discusses how franchise businesses use the Internet, in general, and e-commerce, in particular. Most publications take the form of short industry articles, rather than academic research (Cedrola \& Memmo, 2009). The comparative immaturity of Internet use within franchising systems may be an explanation for this (Rao \& Frazer, 2010). However, the proliferation of franchising and e-commerce as distinct business strategies, and the inherent difficulties that may arise in operations, marketing, and legal obligations from franchising firms developing their own online marketing and retail channels, make it imperative that this gap in the research is filled (Dixon \& Quinn, 2004). In addition, 
further research of the use of e-commerce in franchise networks was specifically called for in recent scholarly work, given the growth potential of e-commerce in franchising and its associated challenges for franchisors as well as franchisees (Perrigot \& Pénard, 2013). This research aims to contribute to this discourse and add to knowledge in theoretical and practical ways.

This research is important from a number of perspectives. Firstly, there is a lack of research into the effect that e-commerce will have on franchising, and the opportunities and threats that it represents for franchisors and franchisees (Dixon \& Quinn, 2004; Weltevreden, De Kruijf, Atzema, Frenken, \& Van Oort, 2005). While implementing e-commerce in franchise systems may potentially improve profitability, reduce costs, and enhance communication and customer service (Pires \& Aisbett, 2003), little is known about how to strategically leverage its capabilities (Rao \& Frazer, 2006). It is especially worth considering the business-toconsumer implications of e-commerce as the effects of this phenomenon hold most controversy for the future of the franchising sector (A. Watson, Kirby, \& Egan, 2002). Secondly, Rao and Frazer (2010) call for further empirical research into the effective use of Internet-based technologies in a franchise system, as they found that while franchisors could envisage the move towards transaction-enabled technology, franchisee acceptance and encroachment were the main reasons preventing them from adopting e-commerce (Rao \& Frazer, 2010). In addition to this, as "the boundaries between 'bricks' and 'clicks' blurs", traditional concepts of geographical and another exclusivity may need to be reconsidered (Abell \& Scott, 2000, p. 2). Thus, the management of franchise relationships and encroachment issues needs to be researched in more depth (Kaufmann, Cliquet, \& Achabal, 2010). 
The qualitative approach to the analysis of this problem will also contribute to knowledge. Cedrola and Memmo (2009) encouraged future studies in this field to include qualitative data through interviewing managers of different franchise businesses. Dixon and Quinn (2004) suggest that surveying the franchisors themselves to analyse their e-commerce strategies will further develop this area of research and provide findings that will benefit franchisors that are currently challenged with the structuring of their e-commerce strategy, the franchising sector as a whole, and franchising relationships, in addition to informing policy. The focal research questions for this paper were, "What is the current state of e-commerce adoption in the franchising sector? How is the adoption of e-commerce affecting franchise relationships and franchisee acceptance of e-commerce? What are the factors contributing to the slow adoption of e-commerce of the franchise sector?"

\section{Literature Review}

\subsection{Franchisor e-commerce: past empirical research}

During the past decade, several studies have addressed the issue of e-commerce in franchising; most of them considered franchisors' use of the Internet and its general role in the franchise system (Cedrola \& Memmo, 2009; Dixon \& Quinn, 2004; Floriani \& Lindsey, 2002; Plave \& Amolsch, 2000; Rao \& Frazer, 2006, 2010), while others specifically focussed on e-commerce engagement (Abell \& Scott, 2000; Plave \& Miller, 2001; Perrigot, Basset, \& Cliquet, 2017; Terry, 2002; Watson et al., 2002).

The latter body of research reveals some insight into the problem being investigated. In their study of 202 Australian franchisors, Rao and Frazer (2006) found that only 11.4\% of franchisors' websites allowed consumers to perform their transactions online. These results are compared with another study undertaken in the UK, where $17 \%$ of 364 franchisors' 
websites were found to offer an e-commerce facility (Dixon \& Quinn, 2004). Meanwhile, Cedrola and Memmo (2009) found that 21\% of a sample of 305 multi-sector and multinational franchisors had a centralised e-commerce facility "to maintain quality and rationalise costs and logistics" (p. 13). The most current research suggests that franchisor engagement in e-commerce has been on the increase and more franchise networks are planning to create an online transactional platform (Frazer, Weaven, \& Bodey, 2012; Frazer et al., 2014; Perrigot, Basset, \& Cliquet, 2017).

Despite recent studies indicating that the trend for franchisor e-commerce is increasing and supporting the argument that e-commerce constitutes a channel of additional sales and marketing in synergy with the physical network, scholars agree that this area is underresearched. In particular, primary data needs to be gathered from franchisors regarding their e-commerce strategies, which is what this study sets out to achieve (Cedrola \& Memmo, 2009; Rao \& Frazer, 2010).

\subsection{Opportunities and threats from B2C e-commerce for franchising}

Like most businesses, franchise organisations typically make use of Internet technologies and e-commerce in various ways to the benefit of their system as a whole (Cliquet \& Voropanova, 2016; Dixon \& Quinn, 2004; Perrigot \& Pénard, 2013). E-commerce may be integrated into operations and marketing to optimise Intranet use, e-procurement, revenue sharing within the system, and interaction with customers (Kaushik et al., 2018; Moriuchi \& Takahashi, 2016; Nisar \& Prabhakar, 2017). However, from the B2C (business-to-consumer) e-commerce standpoint, this business strategy is controversial for franchising. Indeed, some research suggests that e-commerce is particularly suited for franchised businesses because of their established brand names and networks of physical stores, and thus have access to a 
broader customer base (Floriani \& Lindsey, 2002; Plave \& Miller, 2001). Other researchers have argued that e-commerce, rather than contributing to the obsolescence of physical retail in some sectors, will lead to the convergence of online and traditional retailing methods (Di Fatta, Patton, \& Viglia, 2018; Kaushik et al., 2018), where bricks-and-mortar retailers will embrace the Internet and virtual businesses will establish a physical presence (Dixon \& Quinn, 2004).

Conversely, Watson et al. (2002) argued that a business-to-consumer application of ecommerce could potentially reduce the need for franchising as a method of achieving business growth and market penetration. The argument maintains that if the majority of goods are to be bought online, the need for bricks-and-mortar stores will diminish and the costs of market entry will decrease accordingly. From the resource-scarcity theory standpoint, it could be argued that the need for franchising will reduce since the requirement for a large capital input will decline (Watson et al., 2002). Furthermore, Dixon and Quinn (2004) have also suggested that, depending on the nature of the core product or service, e-commerce could theoretically eliminate the need to franchise.

Alternatively, from the dual-marketing point of view, e-commerce is seen as a medium that provides opportunities to franchises to promote their brand, products, or services to customers and to recruit franchisees (Abell \& Scott, 2000; Cedrola \& Memmo, 2009). Additionally, ecommerce may benefit franchised retailers in the long term if they can obtain the benefits of an integrated multi-channel approach (Cliquet \& Voropanova, 2016; Watson et al., 2002), as the Internet gives companies the ability to establish enduring relationships with their customers (Kaushik et al., 2018; Nisar \& Prabhakar, 2017). Although e-commerce can improve operations and profitability of the franchise businesses, the convergence of these two 
dynamic business sectors presents legal and commercial challenges, particularly with respect to encroachment (Terry, 2002).

\subsection{Territorial rights and encroachment}

Encroachment - territorial or other business expansion by the franchisor that invades the actual or perceived rights of an existing franchisee-is argued to be the greatest challenge to the dissemination of e-commerce into the franchising sector (Terry, 2002). For example, encroachment may create conflict when franchisors expand in already developed markets by allowing the website of new franchisees or the franchisor to take away actual or perceived sales from existing franchisees (Fox \& Su, 1996).

The tension is created by conflicting views of franchisors and franchisees. From the franchisor's perspective, encroachment may be often referred to as "network expansion conflict" and viewed as a necessity in business growth (Purvin, 1994, p. 129). Conversely, from the franchisee's perspective, it is regarded as cannibalisation, which represents the franchisor expanding its network and improving their bottom line at the expense of its longstanding franchise partners, who have worked hard to establish the franchisor's business and brand. Thus, the introduction of e-commerce into a franchise network may lead to product and service encroachment (Terry, 2002).

From this perspective, online sales can have an enormous impact on the franchise relationship (Emerson, 2010). This research aims to alert franchisors to ensure that safeguards are in place to protect franchisees and to avoid possible litigation, such as in the case for Dymocks (Terry 2001), or Drug Emporium, another landmark case on Internet encroachment (Knack \& Bloodhart, 2001), where ill-considered e-commerce strategies were selected that were not integrated with bricks-and-mortar franchised stores. 


\section{Methodology}

An overarching qualitative approach was chosen for this study, owing to the scarcity of published research that combines franchising and e-commerce (Cedrola \& Memmo, 2009) and the need to explore the issues pertaining to e-commerce development in Australian franchising networks (Rao \& Frazer, 2010). This exploratory study was undertaken to understand the current state of e-commerce adoption in the Australian franchise sector and the challenges it faced. The data were gathered through a two-stage process that involved (1) semi-structured telephone interviews with franchisors and (2) a moderated industry forum where franchisors and industry experts openly discussed their strategies and concerns with respect to e-commerce. While the interviews allowed for the identification of issues and challenges with individual participants, the forum enabled an open exchange of ideas between participants and co-generation of rich data.

Stage 1. Semi-structured interviews were conducted with 51 senior franchisor executives (for example, CEOs, CFOs, marketing managers, and operations managers; for full demographic data, see Appendix A). Since this research was done in partnership with an Australian franchise consulting company, the access to the participants was gained through their database. An email invited participants to partake in this research through a telephone interview. Purposeful sampling was used (Eisenhardt, 1989; Huberman \& Miles, 1994) to select participants that would represent a larger population, more specifically franchise organisations in Australia employing or considering employing e-commerce strategies in their traditional service or retail business. The interview script was relatively structured, with questions focussing on e-commerce strategies and practices, using criteria elaborated by previous research (Cedrola \& Memmo, 2009; Dixon \& Quinn, 2004; Rao \& Frazer, 2006). 
The questions asked focussed on, first, the current state of development of their e-commerce strategy, the results and expectations from their online sales, and impediments to venturing into e-commerce. Second, we asked about the role of franchisees in the execution of online sales and respective profit sharing, as well as franchisees' attitudes towards e-commerce, if franchisees have been involved in developing the strategy, supported it, or opposed it, and how the introduction of e-commerce impacted the franchisor-franchisee relationship. Last, the franchisors were asked about their perceived impact of e-commerce on their business and the main challenges they encountered in this area. In preparing for these interviews, we reviewed the websites of the participating companies to better appreciate the nature of their business as well as their state of e-commerce development, referring to a set of questions elaborated by other researchers (Cedrola \& Memmo, 2009; Dixon \& Quinn, 2004; Rao \& Frazer, 2006). This preparation phase also enabled us to probe for specifics when asking questions.

Stage 2. The second stage of this exploratory research phase consisted of a moderated open discussion forum organised by an Australian franchise consulting company. The forum was held as a full-day event where 70 senior franchisor executives and e-commerce experts exchanged knowledge and experience on how franchise networks can address the challenges presented by e-commerce, as well as take advantage of the opportunities offered. Facilitated by a moderator, the event consisted of (i) case study presentations followed by an open exchange and (ii) roundtable discussions where participants deliberated on e-commercerelated topics that were identified as holding the most uncertainty for the sector, such as organising logistics and distribution, gaining franchisee acceptance, and dealing with legal issues. The roundtables were chaired by an expert in the topic and the outcomes were recorded by nominated note-takers. In addition, notes were taken throughout the day in order 
to capture the key themes of the case study presentations and the open exchange that followed. The aim was to explore the issues emerging from the interview stage further in the forum to gain better insight.

Approaches. Two different approaches were used to interpret the empirical materials gathered during this research. Firstly, a descriptive analysis of the materials was conducted and, as a result, the understanding of the current state of e-commerce in franchising and the challenges was gained. Secondly, a more in-depth analysis through the three-level coding of the empirical materials collected during this phase of investigation allowed for the identification of certain concepts and themes with respect to the research questions. The materials collected were analysed with the help of the QSR NVivo 10 qualitative software package, using coding and thematic analysis (Bazeley, 2007; Gahan \& Hannibal, 1998; Richards, 1999) (Silverman, 2010). First, the interview responses recorded in the Microsoft Excel spreadsheet were imported into NVivo as a dataset. Notes were recorded from the qualitative responses. Next, the responses were categorised into organisational codes (Maxwell, 2013). Other materials were imported into the software, including all written notes, presenters' slides, and memos (notes made after the forum). Similarly, these materials formed part of the analysis. Subsequently, a hard copy of organisational codes was produced and reviewed to move the analysis further to substantive codes (Maxwell, 2013). Substantive codes were then used to present the text data in a visual form, using the 'models' tool in NVivo that facilitates developing models from coded data (Bazeley, 2007). This step enabled further understanding and interpretation, which helped make the codes more abstract, linking them with theory and key underpinning themes. Models were also instrumental in presenting data in this paper, together with illustrative quotes. Finally, the coding and interpretation process followed Maxwell's coding scheme (Maxwell, 2013). 


\section{Findings and Discussion}

This section is structured to report two levels of analysis in a consecutive manner. The descriptive analysis is reported first, followed by the thematic analysis. In the first phase, the franchisors interviewed represented a multi-sector sample with established networks of franchisees (with a mean of 162 franchised stores or franchise operators) and a recognisable brand name. The sample, which was represented by most major sector industries, as categorised in Franchising Australia Surveys (Frazer et al., 2010, 2012; Frazer et al., 2014), included retail trade, accommodation and food services, administration and support services, and other services. The findings deriving from this research phase were combined under the themes presented below.

\subsection{Descriptive analysis}

\section{$\underline{\text { 5.1.1 Current state of e-commerce and online sales }}$}

The interview stage revealed the franchisors' high level of interest in the subject of ecommerce through their eagerness to participate in the research and to obtain the resulting report. The analysis indicated that one third of the companies already had a web-based facility where customers could purchase their products online, while the remaining two thirds of the franchisors did not have a functioning e-commerce platform. Those with established ecommerce found that around 2 to $5 \%$ of their sales occurred online; however, many found that their online purchasing facility generated a substantial amount of leads and/or in-store sales. These results are consistent with those found in recent Franchising Australia surveys (Frazer et al., 2012; Frazer et al., 2014). Over $80 \%$ of those in the current study, who did not have an e-commerce component in their business, had decided to implement one and were 
either in the testing phase $(35 \%)$ or had decided to proceed but were still investigating how the technical, financial, and operational aspects will work (50\%).

Those who decided to proceed with e-commerce and were close to launching expected, on average, about 2 to $5 \%$ of their sales to occur through an online channel; however, once again, they claimed to rely on their e-commerce platform as an alternative marketing channel more than as a direct sales tool. Their expectations were based on competitor information and national industry research as well as overseas experience of the same industry or brand.

The majority of franchisors who were engaging in e-commerce or were planning to do so in the near future indicated that they intended to share profits generated online with their franchisees, the percentage of which varied from $100 \%$ (usually less a minor transaction/administration fee) to zero. A few franchisors said that all the revenues generated online would be transferred to the marketing fund, while most others explained that profits would be split between individual franchisees and the marketing fund or a special "online marketing fund."

\subsubsection{Franchisor-franchisee relationships and franchisee involvement}

The majority $(95 \%)$ of franchisors indicated that their franchisees were involved in developing the e-commerce strategy for their network, either actively involved $(50 \%)$ by forming steering/consultative committees or providing regular feedback on certain aspects or involved to a lesser degree (45\%). Only $5 \%$ of franchisors reported that their franchisees were not involved at all in the process of elaborating the strategy. 
Additionally, the analysis of the forum discussions suggests that franchisee involvement in executing strategy has to be determined based on, firstly, the nature of the franchise and, secondly, the logic behind distribution arrangements for e-commerce. The manner in which franchisees will be involved has to be carefully considered as this will have an impact on the profit-sharing model. The strategic decision around execution is crucial to the success of any online business, as the inability to fulfil orders timely and adequately is one of the leading reasons for failure in e-commerce (Plave \& Amolsch, 2000).

The franchisee attitudes towards their network's e-commerce strategies that were reported by the interviewed franchisors revealed encouraging comments related to e-commerce. The majority of the franchisors (75\%) believed that their franchisees were "happy with", "supported", and even "pushed" the decision to sell online. According to some, franchisees especially enjoyed the fact that through online sales they could acquire an additional "source of income without having to do anything." However, some franchisors admitted that initial reactions towards online sales were mixed and they had gained franchisee acceptance through consultation and open communication. Others (approximately 15\%) reported that their franchisees were currently unsure or had mixed feelings about online sales for their network. A small percentage of franchisors disclosed that their franchisees were "scared" or "concerned" about the operational side of online sales or that the franchisor will compete with them.

Nearly two thirds $(65 \%)$ of the franchisors reported that e-commerce had a positive impact on their relationship with franchisees, similar to any other innovation initiative that was successfully implemented, thus assisting the franchise network to remain competitive. 


\subsubsection{Challenges}

The main challenges identified by franchisors were as follows: (1) operational (execution and integration of online and in-store environments); (2) financial (deciding on the pricing and revenue structures); (3) relationships (working with franchisee expectations and buy-in); (4) legal (managing franchise agreements, exclusivities of franchisee territories and pricing); (5) logistics and distribution (organising supply chain logistics, managing stock); (6) customer service (managing the customer experience, both in-store and online); and (7) technological (for example, adapting websites and e-commerce facilities for mobile devices). The challenges identified in the first stage of this research were used as roundtable topics at the industry forum to inform the second stage of the investigation.

The following comment by one of the forum participants encapsulates the most significant challenges currently faced in franchising in relation to e-commerce: "The critical issue is that franchisees are key stakeholders. Thus, trust, culture, and the relationship itself are at stake, not just the money. Therefore, acting decisively without careful consideration of all stakeholders can be just as fatal as failing to act."

\subsubsection{Operational aspects of e-commerce strategies}

The integration of online and in-store environments was recognised as a concern by most participants: "How to integrate online model into our bricks and mortar locations is the greatest challenge here", "The inventory is quite different across stores and also returns and exchange policy, if a customer buys online and wants to exchange in-store", "...achieving uniform brand and trying to mitigate the gaps in experience for the customer regardless of whether they shop online or in-store", "...conceptualising the in-store experience for online", "integration of consumer experience from the point of view of customer service and product". 
The most successful integration strategy for retail networks was a model whereby customers order their product online and pick it up in the store. This model was found useful in connecting the marketing and distribution channels, creating certainty and convenience for customers and enhancing customer-franchisee relations, as well as adding value to the sale completed online. The research revealed that an ongoing training program might be required for franchisees and their staff to educate them on the online side of the business to ensure that the virtual and physical store environments are aligned under a consistent brand image and values. Training programs like these would include both the e-commerce component and online presence in general, as the two are interlinked.

\subsubsection{Financial aspects of e-commerce in franchising}

Financial aspects of engaging in e-commerce were also subject to debate. The costs of setting up and maintaining an online store were discussed and were found by many to be equivalent to the setup costs of one franchise outlet. Since many franchisors admitted that the costs were initially underestimated, it is important that profit-sharing arrangements are finalised after all the costs have been calculated: "It ended up costing us a lot more than we initially thought it would, as we had to change a few e-commerce provided before we found the right one." The literature also supports the importance of estimating the costs of initial investment correctly to maintain a healthy relationship with franchisees (Knack \& Bloodhart, 2001). Also, the costs depend on a number of factors, such as whether there are consultants involved in the process of setting up an e-commerce platform, and whether the site is managed in-house or by a third party.

\subsubsection{Franchising relationships and franchisee acceptance}


In line with a proposition made by Dixon and Quinn (2004), and with the findings of Rao and Frazer (2010), this study found that franchisee acceptance of e-commerce strategies is a major challenge that franchisors face: "Making sure that all franchisees have embraced the new system has been the hardest aspect", "They have fears that the online will cannibalise their business", "We've had a full gamut of emotions on this topic within out network over the past 10 years, we've had to work through fears that the franchisor would steal their customers, etc."

As such, franchisors need to have a thoughtful approach when releasing these strategies to an entire network to avoid raising unnecessary confusion and fear among franchisees. Strategies must be well-considered and costs carefully calculated before they are presented to a wider group of franchisees. Moreover, franchisee involvement in the strategy is crucial to ensure franchisee acceptance and successful implementation through the entire franchise network (Davies, Lassar, Manolis, Prince, \& Winsor, 2011; Anna Watson \& Johnson, 2010).

\subsubsection{Territorial rights and other legal considerations}

Finally, legal aspects of e-commerce for franchising initiated much concern among the participants: "We had legal challenges as our franchise agreement prohibits the franchisor from imposing retail prices onto the franchisees and this is what the e-commerce system might do." It was found to be inadvisable to use marketing fund money for paying the setup costs of the e-commerce platform as it could potentially cause legal complications, such as those encountered in the Dymocks case (Dymocks Holdings Pty Ltd v Top Ryde Booksellers Pty Ltd, 2000). Furthermore, it is necessary to review the franchise agreements and consider the territorial rights of franchisees as well as any provisions regarding the ownership rights pertaining to the registration of domain names, which many franchise agreements either omit 
or do not regulate adequately. With regard to pricing, consumer protection laws and other relevant legal obligations need to be considered.

\subsection{Thematic analysis}

Through three-level coding using NVivo10 software, key themes that emerged from the interpreted empirical materials were identified in relation to franchisee acceptance and are presented in this paper: franchisee acceptance with favourable and unfavourable factors for acceptance, and the process of gaining franchisee acceptance and buy-in with regard to introducing and implementing an e-commerce strategy within an existing franchising model. Finally, an overarching model was created where all key concepts are interrelated and avenues for further research are explored.

\subsubsection{Factors positively influencing franchisees' acceptance of e-commerce}

One of the aims of this research was to find out why franchisees may embrace or resist the introduction of e-commerce to their businesses. The responses received from the participants covered a wide array of feelings, opinions, and fears, based on a number of different reasons. The spectrum of feelings ranged from total acceptance to outright rejection of this business strategy and will be discussed in this order below.

The majority of respondents (75\%) reported a positive and supportive attitude of their franchisees towards their network's move into the e-commerce domain, despite the fact that many of them encountered difficulties and "teething at the start" of this journey. Through thematic analysis, four main reasons that motivated franchisees to embrace e-commerce were identified. 
Firstly. E-commerce was reported to assist franchisees in increasing their sales and attracting more customers. Especially positive responses were given by those franchisees whose system was designed in a way that reduced their workload since customers could largely perform self-service through online channels. Therefore, franchisees were more satisfied with the system that they were able to "make money in their sleep" and having "an additional source of income without having to do anything."

Secondly. The e-commerce component was seen to generate leads and direct customers back to the store. There was a consensus among franchisors that franchisees tend to embrace a new strategy more favourably when they see it work in practice. As the technology behind the websites allows for sophisticated tracking of information on customers and lead generation, the statistics from the back end of the website can be used to demonstrate to franchisees the impact that the website is having. One of the franchisors reported as much as " $40 \%$ of all enquiries coming from the website", and unsurprisingly, their franchisees being "well engaged" in the strategy.

Thirdly. The e-commerce platform was seen as a way to provide additional marketing benefits to the franchisees, as they are able to better promote their business to their local market.

Finally. Franchisees recognised the tendencies of the current marketplace and the need for their network to go online in order to stay competitive and thrive. They realised that it was "crucial for their business" and "something that must happen" and understood that this was "the way the market was moving." The model below summarises and illustrates with quotes why franchisees embrace e-commerce (Figure 1). 


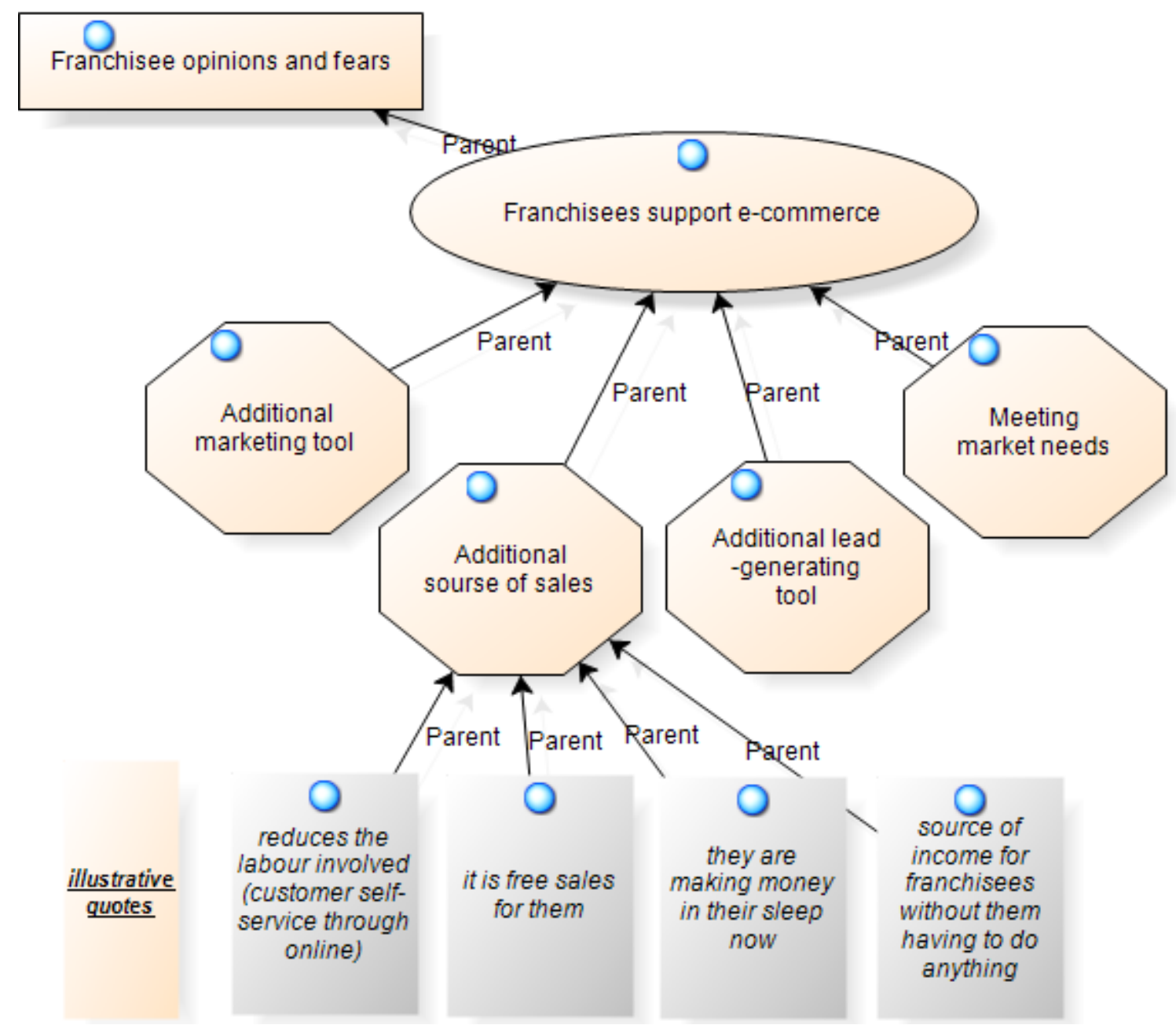

Figure 1: Why franchisees accept e-commerce?

\subsubsection{Factors adversely influencing franchisees' acceptance of e-commerce}

The findings discussed below illustrate various concerns of franchisees surrounding the introduction of e-commerce into their network's business. A myriad of concerns was reported by the franchisors, ranging from fear of the unknown and lack of trust in the franchisor to issues associated with technology use and additional costs. All of these concerns, whether rational or irrational in nature, could be potential barriers for effectively managing and implementing change. The model below (Figure 2) summarises concerns and fears that 
franchisees were reported to have in relation to the introduction of e-commerce. The size of the circle corresponds with the number of references to a certain fear or a concern.

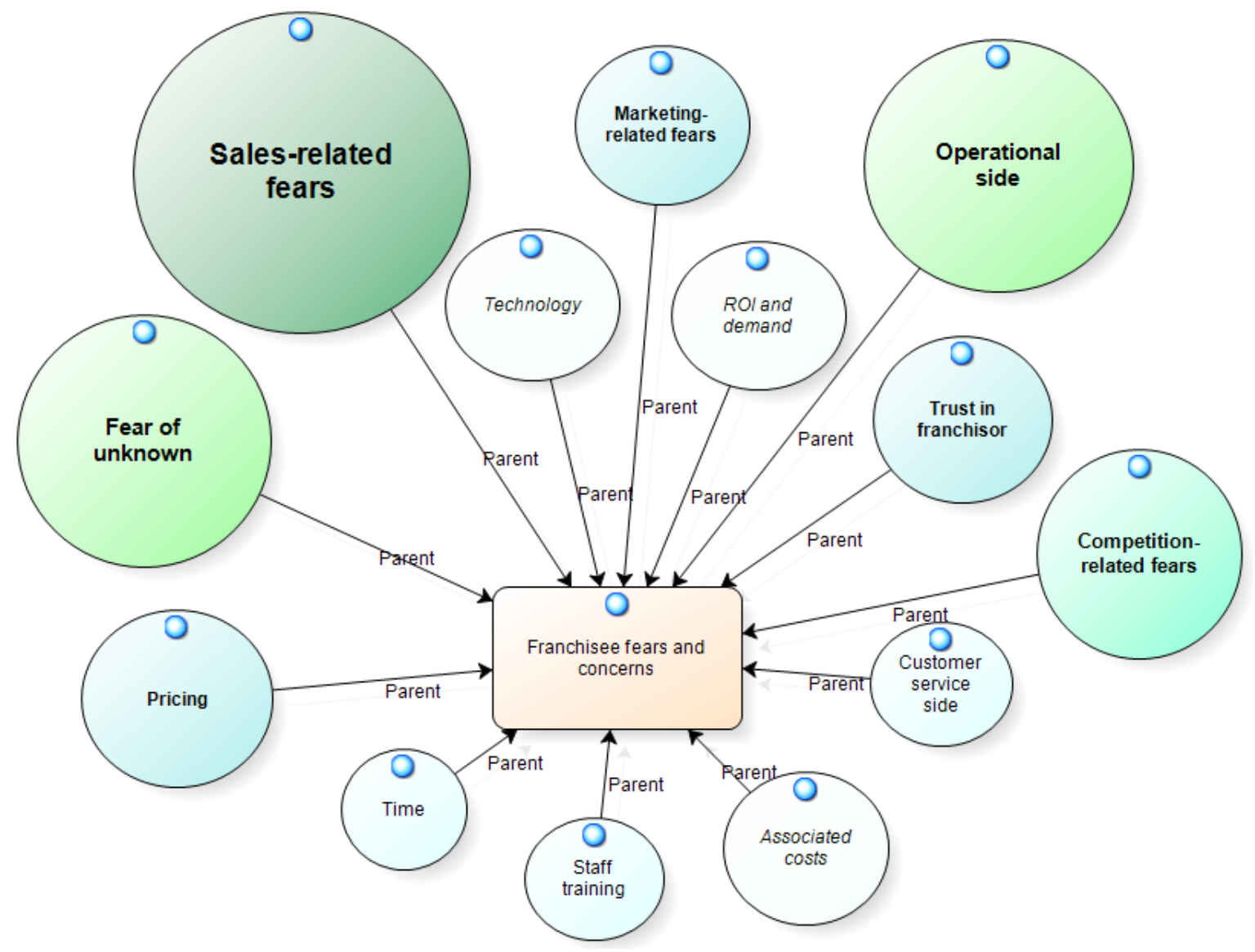

Figure 2: Why franchisees resist e-commerce?

Some of the most common concerns were around sales-related fears (such as losing sales or existing customers to other pure online players), fear of the unknown (due a new technology or lacking information about the change), pricing (that online will be cheaper than RRP), operational concerns (regarding integration of e-commerce), and "fear of the franchisor becoming their direct competitor."

Interestingly, franchisees in different systems had opinions on the two opposite sides of the emotion spectrum that related to the same operational aspect. For example, some of those 
systems, structured in a way where franchisees had to upload product information and specials online, encountered resistance as the online component created more work for them: "They hate it, it means they have to do a lot of extra work, e.g. maintain stock levels, market their specials, upload things onto the online system; they have not embraced it at all."

Conversely, franchisees from other systems complained about the exact opposite, that the system was too automated and that it deprived them of giving each customer "personalised service experience." Another example related to the impact of e-commerce on local area marketing; while it has been identified by some franchisors as a way of improving local area marketing, others have had complaints specifically about this aspect of their business being undermined by e-commerce.

\subsubsection{Gaining franchisee acceptance}

The model below (Figure 3) was developed to demonstrate different ways that franchisors used e-commerce in order to achieve a smoother implementation of change in their systems. 


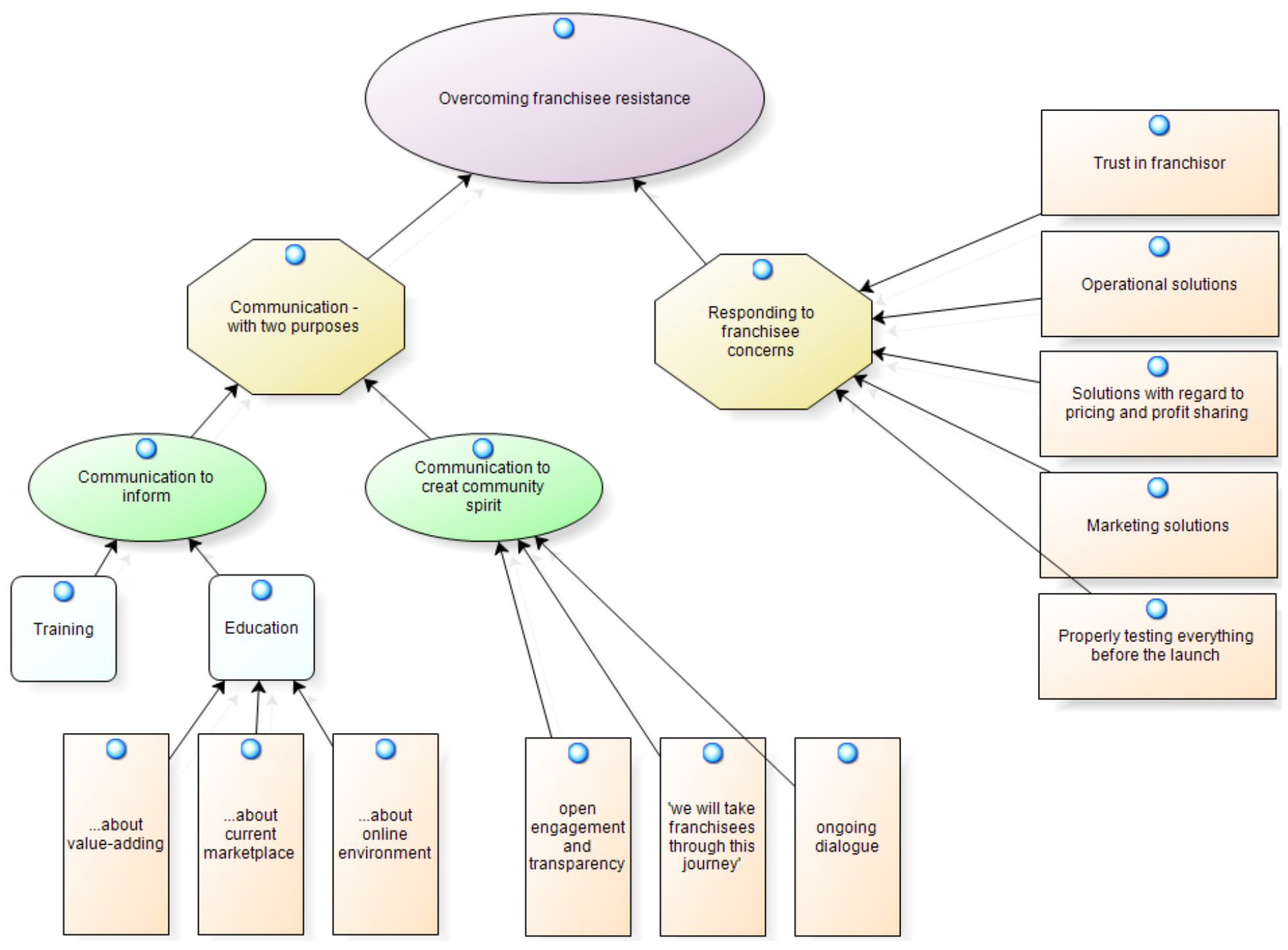

Figure 3: How to overcome franchisee resistance? 
The first crucial strategy was clear, consistent, and timely communication with the franchisees about the change of introducing e-commerce. In line with organisational change theory literature (Elving, 2005), communication needs to be delivered with two purposes in mind: 1) informing franchisees and providing them with education and training regarding the change, and 2) creating "community spirit." The latter can be achieved by creating an open dialogue by encouraging franchisee engagement and by committing to transparency and franchisee support.

Another key strategy to overcoming franchisee resistance to change was through answering franchisee concerns and reflecting them in the policy and implementation process. For example, when franchisees had concerns about the franchisor's website competing with them by offering products for less than the RRP, one of the solutions was not to compete on the price basis with other online players but rather to compete on the basis of service, product quality, and convenience for customers. This strategy would reinforce the trust in the franchisor and demonstrate to the franchisees that the franchisor is not trying to undermine the franchisees' business but rather to seek ways to improve the competitiveness of the whole network.

\subsubsection{Model developed based on this research}

An overarching preliminary model was developed that comprised four intertwined key themes: resistance to change, communication (and franchisee education/training), relationships, and stakeholders. In line with extant organisational change literature (Elving, 2005), it is hypothesised that resistance to change can be minimised, and therefore franchisee acceptance increased, through extensive involvement of key stakeholders (franchisees) and 
careful consideration of relationships with them. This can be achieved through communication and education/training of the franchisees. As explained earlier in this paper, communication during a change process can be done with two purposes: to inform and to create a community spirit. If undertaken successfully, communication can increase readiness for change and decrease resistance to change. From the analysis of the empirical materials, as represented in Figure 4, it became evident that this kind of communication can be done through several communication channels (and technology) available today to most businesses. 


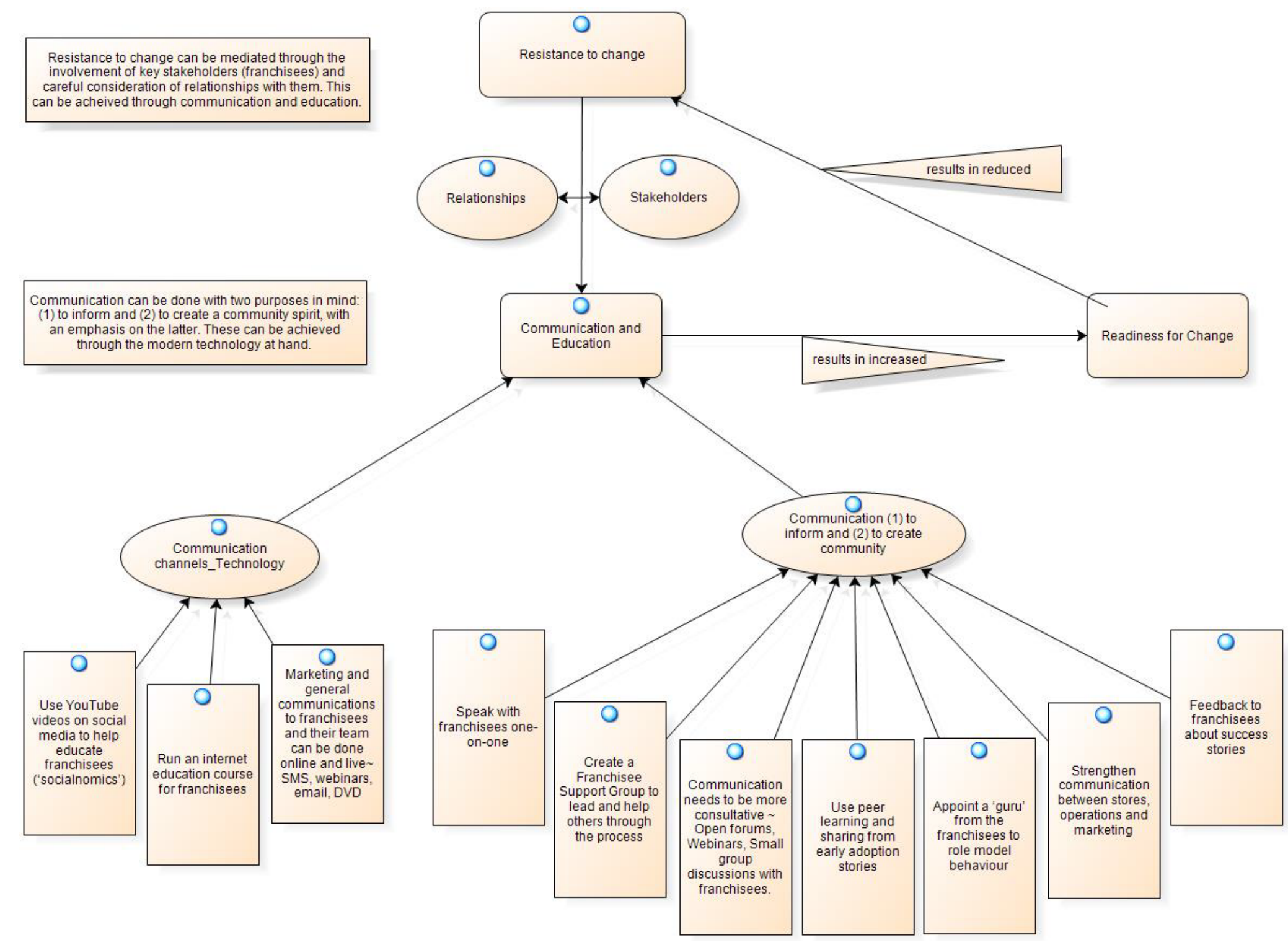

Figure 4: A preliminary model for e-commerce introduction in franchising 


\section{Practical Implications}

Franchising professionals could learn several key lessons from this research.

The involvement of franchisees and open communication. Franchisors should involve franchisees in developing their system's e-commerce strategy. The communication about the forthcoming change and its implementation should be timely, clear, consistent, and regular, and underpinned by the values of transparency and mutual benefit of the franchisor and the franchisees. The views of both franchisor and franchisees need to be taken into consideration if a franchising relationship is to work as a genuine partnership. As encroachment is a sensitive issue and e-commerce embodies such an important strategic decision, the unilateral action by the franchisor could potentially limit cooperation and have a negative overall effect on the franchisor-franchisee relationship (Hellriegel \& Vincent, 2000).

For franchisors integrating e-commerce into an existing system (that was not initially designed to incorporate the impact of online sales on franchisee territories), the only approach to developing a successful e-commerce policy and strategy is collaboratively with franchisees (Terry, 2002). Involving franchisees in the development of the network's e-commerce strategy and policy can also benefit the franchisor-franchisee relationship in general (Abell \& Scott, 2000; Hellriegel \& Vincent, 2000). Alternatively, franchisors who exclude franchisees entirely from the decisions around e-commerce could even face legal action if they are violating franchise or competition laws (Abell \& Scott, 2000).

Developing e-commerce strategies. Franchisors need to take a few important considerations into account when developing e-commerce strategies for their business. First, the significant initial investment that e-commerce strategy requires should not be underestimated; doing so 
may lead to failure to deliver on promises to franchisees (Knack \& Bloodhart, 2001). Second, timely fulfilment of customer orders is essential to the success of any e-commerce strategy, as the inability to fulfil orders properly and promptly was found to be one of the leading causes of failure for e-commerce businesses (Plave \& Amolsch, 2000). Therefore, a strong emphasis on smooth operational integration is required.

Third, there is an important opportunity for using the Internet to develop meaningful and lasting relationships with customers, as well as offer customers a multi-channel retailing experience, that can be done effectively through various Web 2.0 technologies. Indeed, the interaction between franchisors and customers via the Internet was found to indirectly strengthen the relationship between franchisor and franchisees (Rao \& Frazer, 2010) due to increased perception of the value of a given franchise system. Finally, key considerations, such as the type of product or service that the franchise system provides, the type of industry, and the degree of impact, need to become the driving forces behind appropriate solutions (Terry, 2002).

\section{Limitations and Future Research Directions}

The findings of this research revealed that the Australian franchising sector made significant progress in e-commerce strategies adoption in the past years, as there is a considerable difference when findings are compared with studies from 2010 and later years (Frazer et al., 2012; Frazer et al., 2014; Rao \& Frazer, 2010).

The reported research allowed for deeper understanding of the phenomenon researched; nevertheless, a more comprehensive approach is needed to further explore this problem (Silverman, 2010). This analysis reflects the data reported by the franchisors, which is a 
limitation, as primary data collected from franchisees would give us a clearer understanding of the franchisees' perspectives. Indeed, most current academic and industry research has assumed franchisors' perspectives on the adoption and use of e-commerce in franchising (Perrigot \& Pénard, 2013). However, there needs to be a more equitable investigation of key stakeholders in a franchising relationship. For example, Dant, Grünhagen, and Windsperger (2011) called for further research of the franchisees' say in decision making in their network to evaluate any shifts in the traditional power imbalance pertaining to this business relationship. Future research where both franchisors and franchisees are interviewed using a multiple case study approach (Yin, 2009) would provide a greater awareness of the whole franchise network view on the e-commerce adoption and integration. We proposed the investigation of the propositions that (1) franchisees and franchisee advisory bodies play a vital part in the formulation of the e-commerce strategy and that (2) the extensive process of consulting with franchisees may result in greater franchisee acceptance, healthier franchisorfranchisee relationships, and more successful outcomes from the e-commerce strategy for the franchise network as a whole.

Further research needs to be aimed at developing a framework of e-commerce for franchising and identifying key strategic considerations that can guide franchisors in developing an online marketing and sales channel for their network and offering a multi-channel experience to their customers. This aim entails the shifting of the research paradigm, from purely descriptive research to prescriptive questions, such as "how should...franchising be done?" as suggested by Wright and McAuley (2012, p. 161). We propose addressing the research questions, such as "How to implement e-commerce into a franchise system?" and "What are the key success factors in integrating e-commerce into franchise operations?" 
Finally, further investigation should aim to develop the underlying area of research in the direction of addressing the "why" questions, so that the theoretical underpinnings can be explored and theoretical contribution can be made to the body of literature pertaining to the nexus between e-commerce and franchising, where scholars consented that empirical research is insufficient (Cedrola \& Memmo, 2009; Dixon \& Quinn, 2004; Perrigot \& Pénard, 2013).

\section{References}

Abell, M., \& Scott, A. (2000). The e-commerce challenge for franchising. Managing Intellectual Property, 101(2000), 34-37.

Bazeley, P. (2007). Qualitative data analysis with NVivo. London: SAGE Publications.

Cedrola, E., \& Memmo, S. (2009). Internet for Franchising: Current Use and Areas of Improvement-Results of an Empirical Research. Journal of Euromarketing, 18(1), 521.

Chumnumpan, P., \& Shi, X. (2019). Understanding new products' market performance using Google Trends. Australasian Marketing Journal (AMJ).

\section{https://doi.org/10.1016/j.ausmj.2019.01.001}

Cliquet, G., \& Voropanova, E. (2016). E-commerce and encroachment: evidence from French franchise networks. Journal of Marketing Channels, 23(3), 114-128.

Dant, R. P., Grünhagen, M., \& Windsperger, J. (2011). Franchising research frontiers for the twenty-first century. Journal of Retailing, 87(3), 253-268.

Davies, M. A., Lassar, W., Manolis, C., Prince, M., \& Winsor, R. D. (2011). A model of trust and compliance in franchise relationships. Journal of Business Venturing, 26(3), 321340. 
Dennis, C., Merrilees, B., Jayawardhena, C., \& Tiu Wright, L. (2009). E-consumer behaviour. European Journal of Marketing, 43(9/10), 1121-1139.

Denzin, N. K., \& Lincoln, Y. S. (Eds.). (2000). Handbook of qualitative research (2 ed.). Thousand Oaks, CA: Sage Publications.

Di Fatta, D., Patton, D., \& Viglia, G. (2018). The determinants of conversion rates in SME ecommerce websites. Journal of Retailing and Consumer Services, 41, 161-168.

Dixon, H., \& Quinn, B. (2004). Franchising and the Internet: an exploratory study of franchisor Web sites. Internet Research, 14(4), 311-322.

E-commerce Report. (2012). Commonwealth Bank says Aussie online retail grew 36\% last year.

Eisenhardt, K. M. (1989). Building theories from case study research. Academy of Management Review, 14(4), 532-550.

Elving, W. (2005). The role of communication in organisational change. Corporate Communications: An International Journal, 10(2), 129-138.

Emerson, R. W. (2010). Franchise Encroachment. American Business Law Journal, 47(2), 191-290.

Floriani, B., \& Lindsey, M. K. (2002). The continuing impact of the Internet on international franchising. Business Law International, 1(1), 86-141.

Fox, B. E., \& Su, H. C. (1996). Franchising law. The National Law Journal, 30, 13-15.

Frazer, L. (2000). Assessing franchising sector maturity: Australian evidence. Australasian Marketing Journal (AMJ), 8(2), 33-46.

Frazer, L., Weaven, S., \& Bodey, K. (2010). Franchising Australia 2010, Brisbane, Australia: Asia-Pacific Centre for Franchising Excellence, Griffith University.

Frazer, L., Weaven, S., \& Bodey, K. (2012). Franchising Australia 2012, Brisbane, Australia: Asia-Pacific Centre for Franchising Excellence, Griffith University. 
Frazer, L., Weaven, S., \& Grace, A. (2014). Franchising Australia 2014, Brisbane, Australia: Asia-Pacific Centre for Franchising Excellence, Griffith University.

Fulop, C., \& Forward, J. (1997). Insights into franchising: a review of empirical and theoretical perspectives. The Service Industries Journal, 17(4), 603 - 625.

Gahan, C., \& Hannibal, M. (1998). Doing qualitative research using QSR NUD* IST: SAGE Publications.

Hellriegel, J. E., \& Vincent, W. S. (2000). The Encroachment Handbook, The Problem, The History, The Solution. Paper presented at the 14th Conference of the International Society of Franchising, San Diego.

Herjanto, H., \& Franklin, D. (2019). Investigating salesperson performance factors: A systematic review of the literature on the characteristics of effective salespersons. Australasian Marketing Journal (AMJ).

https://doi.org/10.1016/j.ausmj.2018.12.001

Huberman, A. M., \& Miles, M. B. (1994). Data management and analysis methods. In N. K. Denzin \& Y. S. Lincoln (Eds.), Handbook of qualitative research (pp. 428-444). Thousand Oaks, CA: SAGE Publications.

Kaufmann, P. J., Cliquet, G., \& Achabal, D. D. (2010). Implementing multi-channel strategies: Issues and opportunities for franchise system websites. Paper presented at the 24th ISoF Conference, Sydney.

Kaushik, K., Mishra, R., Rana, N. P., \& Dwivedi, Y. K. (2018). Exploring reviews and review sequences on e-commerce platform: A study of helpful reviews on Amazon. in. Journal of Retailing and Consumer Services, 45, 21-32.

Knack, G. L., \& Bloodhart, A. K. (2001). Do Franchisors Need to Rechart the Course to Internet Success. Franchise Law Journal, 20, 133-147. 
Maxwell, J. A. (2013). Qualitative research design: an interactive approach. Thousand Oaks, CA: Sage.

Merriam, S. B. (2009). Qualitative Research: A guide to design and implementation. San Francisco, CA: Jossey-Bass.

Michael, S. C. (2002). Can a franchise chain coordinate? Journal of Business Venturing, 17, $325-341$

Moriuchi, E., \& Takahashi, I. (2016). Satisfaction trust and loyalty of repeat online consumer within the Japanese online supermarket trade. Australasian Marketing Journal (AMJ), 24(2), 146-156.

Nathan, G., \& Kremez, Z. (2012). The e-commerce tipping point for franchising. Franchise New Zealand.

Nisar, T. M., \& Prabhakar, G. (2017). What factors determine e-satisfaction and consumer spending in e-commerce retailing?. Journal of Retailing and Consumer Services, 39 , 135-144.

Perrigot, R., \& Pénard, T. (2013). Determinants of E-Commerce Strategy in Franchising: A Resource-Based View. International Journal of Electronic Commerce, 17(3), 109-130.

Perrigot, R., Basset, G., \& Cliquet, G. (2017). E-commerce opportunities and challenges for franchise chains. In Handbook of Research on Franchising. Edward Elgar Publishing.

Pires, G. D., \& Aisbett, J. (2003). The relationship between technology adoption and strategy in business-to-business markets: The case of e-commerce. Industrial Marketing Management, 32(4), 291-300.

Plave, L. J., \& Amolsch, R. B. (2000). How to Implement Dot.com Franchising Solutions: Two Aspects of A Multi-faceted Issue. Franchising World, September/October, 17-19. 
Plave, L. J., \& Miller, K. M. (2001). International Franchising \& E-Commerce: Adapting Franchise Systems to the Global Electronic Marketplace. International Journal of Franchising and Distribution Law, 3(4), 259-313.

Purvin, R. L. (1994). The Franchise Fraud. New York: John Wiley \& Sons.

Rao, S., \& Frazer, L. (2006). Australian Franchisor websites: Moving towards network behaviour. Journal of Theoretical and Applied Electronic Commerce Research, 1(1), $56-64$.

Rao, S., \& Frazer, L. (2010). The use of Internet-based technologies in Australian franchise systems: A preliminary study. Journal of Internet Business, 2(1), 1-23.

Richards, L. (1999). Using NVivo in qualitative research: SAGE Publications.

Schneider, G. P. (2011). Electronic commerce. Boston, MA: Course Technology Cengage Learning.

Silverman, D. (2010). Doing qualitative research. Thousand Oaks, California: Sage publications, Inc.

Stafford, P. (2011). Harvey Norman launches online store - five things we love, and five things we don't. Start Up Smart. http://www.startupsmart.com.au/growth/harveynorman-launches-online-store- $\%$ E2\%80\%93-five-things-we-love-and-five-things-wedont/201111244656.html

Tagashira, T., \& Minami, C. (2016). The effects of online and offline information sources on multiple store patronage. Australasian Marketing Journal (AMJ), 24(2), 116-124.

Terry, A. (2002). The e-business challenge to franchising. Australian Business Law Review, 30(3), 227-241.

Trinh, G. T., Anesbury, Z. W., \& Driesener, C. (2017). Has behavioural loyalty to online supermarkets declined?. Australasian Marketing Journal (AMJ), 25(4), 326-333. 
Vincent, W. S. (1998). Encroachment: legal restrictions on retail franchise expansion. Journal of Business Venturing, 13(1), 29-41.

Watson, A., \& Johnson, R. (2010). Managing the Franchisor-Franchisee Relationship: A Relationship Marketing Perspective. Journal of marketing Channels, 17(1), 51-68.

Watson, A., Kirby, D. A., \& Egan, J. (2002). Franchising, retailing and the development of ecommerce. International Journal of Retail \& Distribution Management, 30(5), 228237.

Weaven, S., Baker, B. L., Edwards, C., Frazer, L., \& Grace, D. (2018). Predicting organizational form choice from pre-entry characteristics of franchisees. Australasian Marketing Journal (AMJ), 26(1), 49-58.

Weltevreden, J. W. J., De Kruijf, K., Atzema, O., Frenken, K., \& Van Oort, F. (2005). The B2C e-commerce landscape of the Dutch retail sector. Paper presented at the 45th Congress of the European Regional Science Association, Amsterdam.

Wright, O., \& Frazer, L. (2007). A multiple case analysis of franchised cobranding. Australasian Marketing Journal (AMJ), 15(2), 68-80.

Wright, O., \& McAuley, A. (2012). Australian franchising research: Review, synthesis and future research directions. Australasian Marketing Journal (AMJ), 20(2), 158-163.

Wright, O., \& McAuley, A. (2012). Australian franchising research: Review, synthesis and future research directions. Australasian Marketing Journal (AMJ), 20(2), 158-163.

Yin, R. K. (2009). Case study research: design and methods. California: Sage Publications. 
Appendix A: Interview participants description table

\begin{tabular}{|c|c|c|c|}
\hline Ref. & Industry & Position in the company of the interviewee & System size \\
\hline 1 & Non-food retail & Chief Operating Officer & 40 \\
\hline 2 & Food retail & General Manager Marketing & 245 \\
\hline 3 & Non-food retail & National Marketing Manager & 30 \\
\hline 4 & Non-food retail & National Advertising Manager & 104 \\
\hline 5 & Food retail & National Marketing Coordinator & 77 \\
\hline 6 & Food retail & co-Managing Director & 24 \\
\hline 7 & Services (fitness) & Software Development Manager & 74 \\
\hline 8 & Mobile services (pet care) & Director & 150 \\
\hline 9 & Non-food retail & National Franchise and Operations Manager & 120 \\
\hline 10 & Services (logistics) & Innovation and Business Systems Manager & 106 \\
\hline 11 & Retail food & Managing Director & 94 \\
\hline 12 & Personal services (mobile) & Managing Director & 47 \\
\hline 13 & Retail & E-commerce Manager & 330 \\
\hline 14 & Personal services (mobile) & General Manager for IT, Marketing and Contact Centre & 210 \\
\hline 15 & Non-food retail & CEO & 160 \\
\hline 16 & Food retail & General Manager & 186 \\
\hline 17 & Food retail & Managing Director & 32 \\
\hline 18 & Financial services & General Manager of Operations and Head of IT Department & 370 \\
\hline 19 & Food retail & General Manager & 147 \\
\hline 20 & Real estate services & Marketing and PR Head & 48 \\
\hline 21 & Food retail & Finance Manager & 28 \\
\hline 22 & Food retail & Marketing Manager & 327 \\
\hline 23 & Services (pet care) & Franchisor - Operations & 11 \\
\hline 24 & Non-food retail & National Sales and Operations Manager & 15 \\
\hline 25 & Food retail & Group Corporate Communications Manager & 609 \\
\hline 26 & Financial services & National Franchise Development Manager & 151 \\
\hline
\end{tabular}




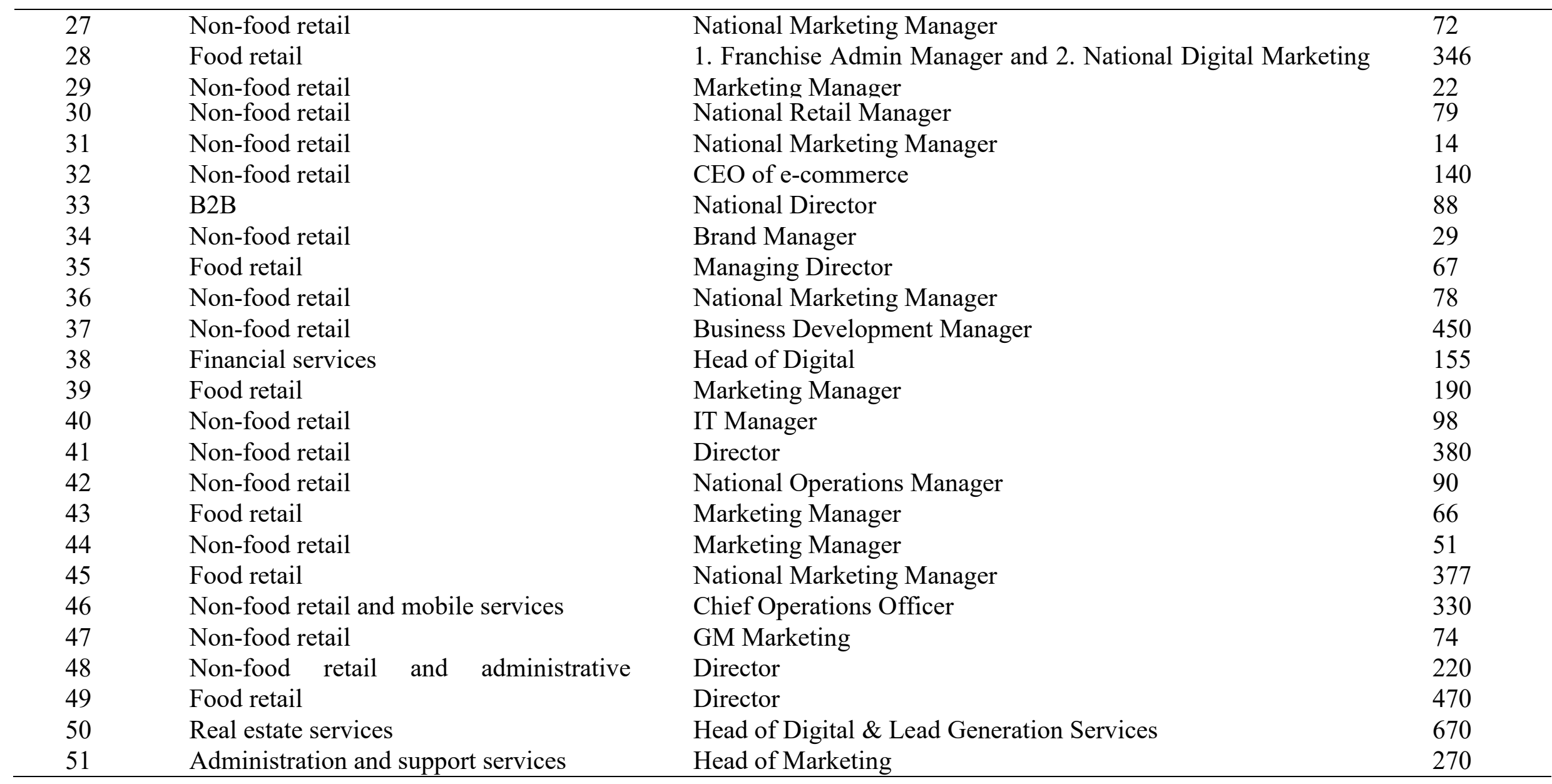

